\title{
Leukemia Inhibitory Factor Measurement
}

National Cancer Institute

\section{Source}

National Cancer Institute. Leukemia Inhibitory Factor Measurement. NCI Thesaurus.

Code C130163.

The determination of the amount of leukemia inhibitory factor present in a sample. 